\title{
KERENTANAN GERAKAN TANAH DI DESA WARUNGMENTENG SUB DAS CIBADAK, LERENG BAGIAN TIMUR GUNUNG SALAK
}

\author{
Undang Mardiana, M. Kurniawan Alfadli, Nanda Natasia, dan Deden Zaenudin M \\ Fakultas Teknik Geologi, Universitas Padjadjaran \\ E-mail: undang.mardiana@unpad.ac.id
}

\begin{abstract}
ABSTRAK. Daerah Warungmenteng dan sekitarnya secara administratif termasuk dalam wilayah Kecamatan Cijeruk, terletak pada lereng timur Gunung Salak merupakan salah satu kawasan yang masuk dalam zona potensi terjadi gerakan tanah tinggi hingga menengah. Penelitian ini bertujuan untuk mengklasifikasikan tingkat kerentanan gerakan tanah di Desa Warungmenteng dengan menggunakan metode Paimin (Paimin, 2006), yang didasarkan karakteristik fisik berupa kondisi geologi, kemiringan lereng, tataguna lahan dan curah hujan setempat. Terdapat tiga tingkat kerentanan gerakan tanah, yaitu agak rentan, rentan dan sangat rentan. Secara umum klasifikasi tersebut menunjukkan bahwa sebagian besar lokasi longsor memang berada pada daerah dengan tingkat kerentanan gerakan tanah sangat rentan. Kerentanan gerakan tanah di daerah penelitian dipengaruhi oleh kemiringan lereng dan litologi atau jenis tanah, serta curah hujan sebagai faktor pemicu terjadinya gerakan tanah.
\end{abstract}

Kata kunci: geologi; kemiringan lereng; tataguna lahan; kerentanan gerakan tanah; Warungmenteng

ABSTRACT. Warungmenteng area and its surrounding is administratively located in Cijeruk Regency area. This area is also located in the east slope of Salak Mountain which is one of the areas included in the potential zone of high to medium soil movement. This study aims to classify the level of vulnerability of soil movements in Warungmenteng Village using the Paimin method (Paimin, 2006), which is based on physical characteristics such as geological conditions, slope, land use and local rainfall. There are three levels of vulnerability to land movements, namely rather vulnerable, vulnerable and very vulnerable. In general, the classification shows that most landslide locations are indeed in areas with a very vulnerable level of land movement vulnerability. Vulnerability of soil movements in the study area is influenced by slope and lithology or soil type, as well as rainfall as a trigger factor for soil movement.

Keywords: geology; slope; land use; land movement; warungmenteng

\section{PENDAHULUAN}

Wilayah Kabupaten Bogor merupakan salah satu daerah yang paling rawan terhadap bencana gerakan tanah di Indonesia. Menurut Badan Penanggulangan Bencana Daerah (BPBD) Kabupaten Bogor bencana alam yang terjadi di wilayah Kabupaten Bogor selama tahun 2018 tercatat sampai dengan Maret sebanyak 259 kejadian yang terdiri dari tanah longsor 77 kejadian, banjir 17 kejadian, kebakaran 16 kejadian, angin kencang 60 kejadian dan lain - lain 89 kejadian, dari semua kejadian tersebut BPBD telah melakukan penanganan kedaruratan sebagaimana mestinya seperti pengiriman logistik bagi korban bencana, evakuasi korban dan puing, bahan material lainnya akibat bencana.

Hal ini terjadi antara lain disebabkan oleh faktor curah hujan yang tinggi, kemiringan lereng yang sangat terjal $>70$ derajat $(100-150 \%)$ dan merupakan daerah yang tergolong rawan gerakan tanah (zona merah), tipe morfologi wilayah yang bervariasi, dari dataran yang relatif rendah di bagian utara hingga dataran tinggi di bagian selatan, yaitu sekitar 29,28\% berada pada ketinggian 15 - 100 meter di atas permukaan laut (dpl); 42,62\% berada pada ketinggian 100 - 500 meter dpl; 19,53\% berada pada ketinggian 500 - 1.000 meter dpl; 8,43\% berada pada ketinggian 1.000 - 2.000 meter dpl dan $0,22 \%$ berada pada ketinggian 2.000 - 2.500 meter dpl. Bogor diguyur hujan setiap bulan, dengan curah hujan tertinggi terjadi pada bulan Januari 2014 yang mencapai 702,0 mm dengan jumlah hari hujan 31, dan terendah pada bulan Agustus yaitu 146,0 mm dengan jumlah hari hujan 14 sehingga hal ini menjadikan wilayah Bogor sangat rawan sekali bahaya longsor.

Penelitian ini bertujuan untuk mengklasifikasikan tingkat kerentanan gerakan tanah di Desa Warungmenteng dengan menggunakan metode Paimin (Paimin dkk., 2006). berdasarkan karakteristik fisik berupa: kondisi geologi, kemiringan lereng, tataguna lahan, dan curah hujan setempat. Informasi klasifikasi kerentanan gerakan tanah di Warungmenteng bermanfaat untuk keperluan tata ruang wilayah dan mitigasi bencana.

\section{METODE}

Lokasi penelitian (Gambar 1) terletak di Desa Warungmenteng, Kecamatan Cijeruk, atau daerah lereng timur Gunung Salak dengan metode analisa tingkat gerakan tanah.

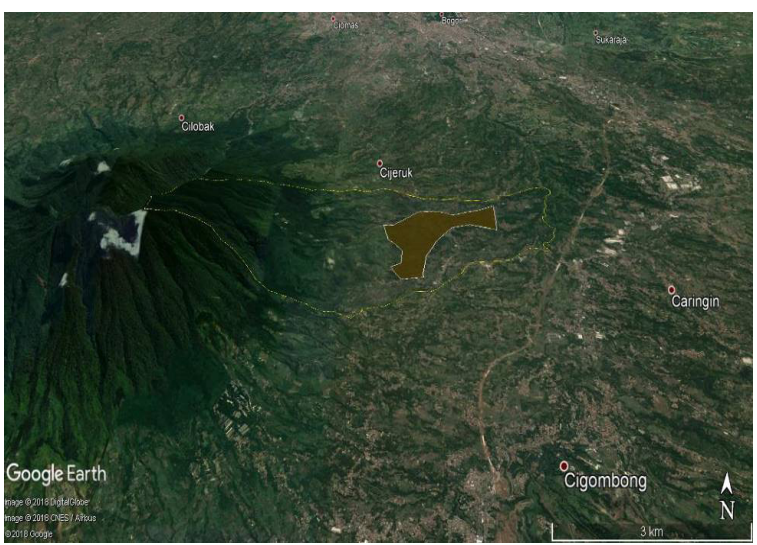

Gambar 1. Lokasi penelitian (sumber: google maps) 
Analisa tingkat kerentanan gerakan tanah dilakukan menggunakan menggunakan formula kerentanan tanah longsor (Paimin dkk., 2006), seperti pada tabel 1. Klasifikasi tingkat kerentanan gerakan tanah dilakukan menggunakan metode Paimin (Paimin dkk, 2006). Parameter yang digunakan dalam klasifikasi tingkat kerentanan adalah curah hujan, kemiringan lereng, geologi/batuan, keberadaan sesar/kerapatan kelurusan, tata guna lahan berupa hutan, sawah, pemukiman, semak belukar. Data tataguna lahan dan elevasi kontur daerah Warung menteng dan sekitarnya didapatkan dari Peta Rupa Bumi Indonesia Skala 1:25.000. Pengaruh faktor geologi didekati dari kepekaan terhadap erosi berbagai jenis tanah hasil pelapukan batuan yang menyusun daerah penelitian. Data curah hujan didapatkan dari data pengamatan yang dilakukan di stasiun Pondok Gedeh. Data curah hujan tersebut diolah sehingga didapatkan tipe curah hujan yang ada di Warungmenteng dan sekitarnya. Pengolahan data masing -masing parameter dilakukan menggunakan perangkat lunak sistem infromasi geografis, untuk selanjutnya dilakukan pengekelasan dan pembobotan. Perhitungan tingkat kerentanan terhadap gerakan tanah dilakukan dengan menggunakan metode Paimin (Paimin dkk .,2006), kemudian dilakukan tumpeng tindih peta - peta parameter fisik untuk menghasilkan peta tingkat kerentanan gerakan tanah (Gambar 2).

\section{Klasifikasi Kerentanan Gerakan Tanah}

Penentuan tingkat kerentanan gerakan tanah menggunakan Indeks Storie yaitu perkalian beberapa parameter yang mempunyai bobot terendah hingga tertinggi. Tingkat kerentanan tanah diasumsikan berdasarkan perkalian tersebut dari nilai bobot maksimum hingga minimum sehingga didapatkan 5 tingkat kerentanan (Tabel 1).
Tabel 1. Klasifikasi zona longsor (Paimin dkk., 2006)

\begin{tabular}{ccc}
\hline No & Skor Tertimbang & Kategori \\
\hline 1 & $>4,3$ & Sangat Rentan \\
2 & $3,5-4,3$ & Rentan \\
3 & $2,6-3,4$ & Agak Rentan \\
4 & $1,7-2,5$ & Sedikit Rentan \\
5 & $<1,7$ & Tidak Rentan \\
\hline
\end{tabular}

\section{HASIL DAN PEMBAHASAN}

\section{Kondisi Geologi Daerah Warungmenteng}

Menurut Natasia (2018) mengenai fasies vulkanik daerah Sungai Ciparakalih dan Sungai Cihideung yang merupakan sebagian dari Desa Warungmenteng, daerah ini tersusun atas Fasies Lapili 1, fasies tuf lapilli 2, fasies lava1, fasies breksi tuff 3, fasies lava 2, dan fasies breksi tuf 4 yang digambarkan pada peta geomorfologi DAS (Daerah Aliran Sungai) Cibadak di bawah ini.

\section{Kondisi Tata Guna Lahan Daerah Warungmenteng}

Pengunaan lahan (gambar 2B) memiliki bobot persentase $40 \%$. Penggunaan lahan terdiri atas pemukiman, sawah, semak belukar, kebun dan hutan. Tata guna lahan pemukiman miliki kategori nilai potensi longsor yang tinggi dengan luas 233,9 ha atau $11,7 \%$. Sedangkan kelas sawah memiliki kategori nilai potensi longsor yang agak tinggi dengan luas 374,9 ha atau 18,7\%; kelas kebun memiliki potensi longsor yang sedang dengan luas 721,9 ha atau $36 \%$. Kemudian kelas semak belukar memiliki potensi longsor yang agak rendah dengan luas 351,5 ha atau $17,5 \%$ dan terakhir kelas hutan memiliki potensi longsor yang rendah dengan luas 318,8 ha atau 15,9 $\%$.
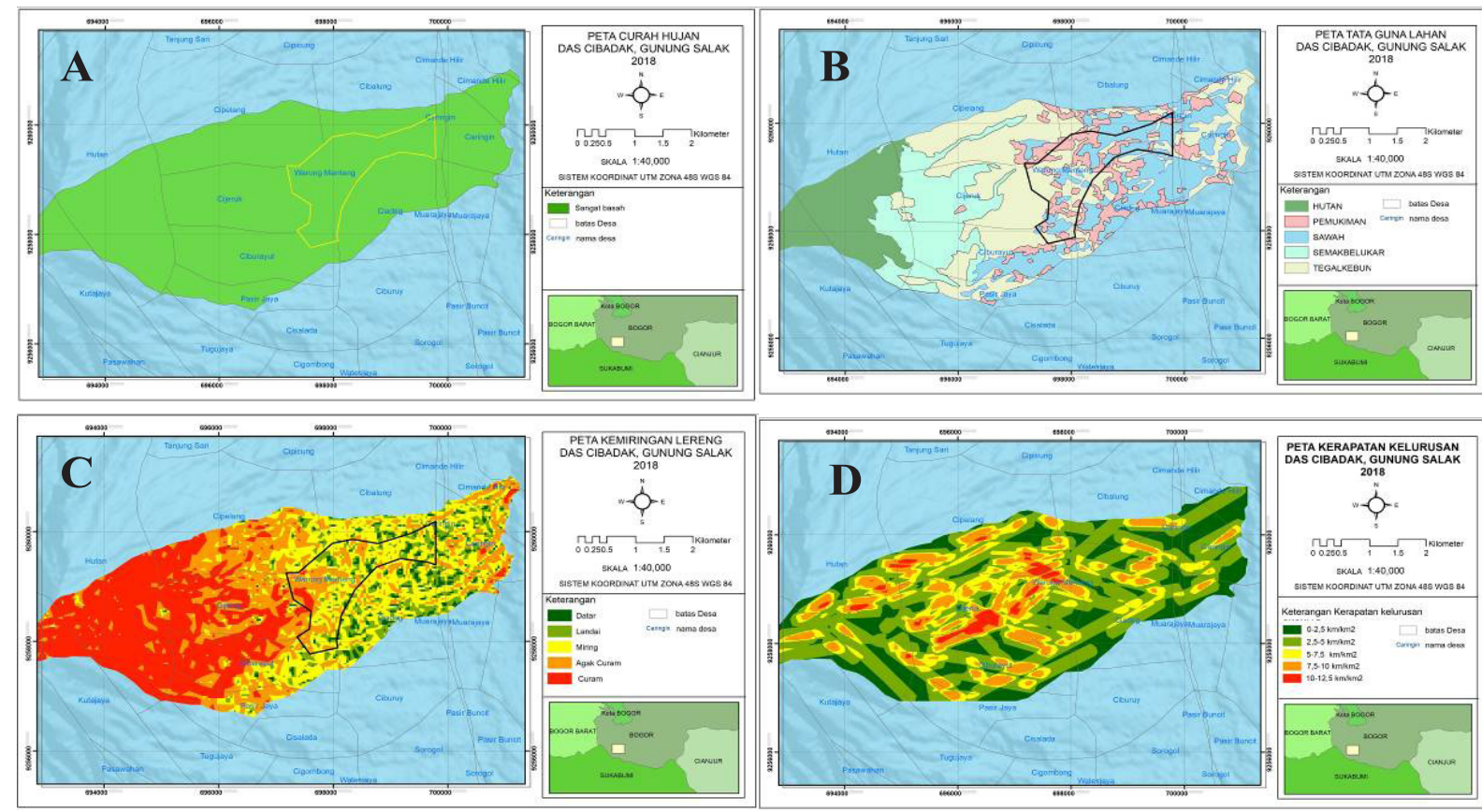

Gambar 2. Peta-peta penyusun formula zona longsor Desa Warungmenteng, Bogor 


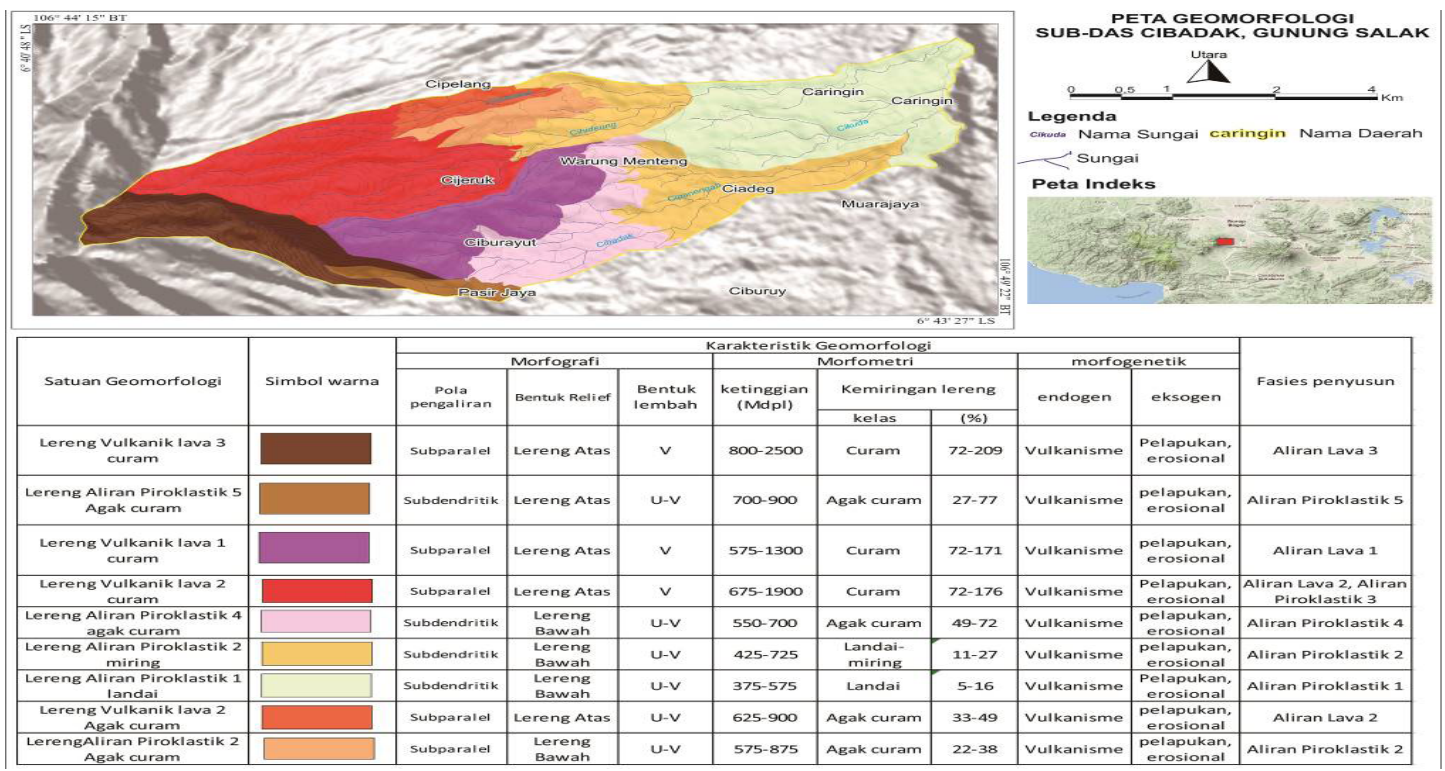

Gambar 3. Peta Geomorfologi Sub-Das Cibadak, Gunung Salak (Natasia, 2018)

\section{Kemiringan Lereng}

Sebagian besar wilayah DAS cibadak merupakan daerah yang curam (gambar 2c), dengan kelas kelerengan diatas 16 yaitu 614,2 ha atau 30,6\% merupakan potensi longsor yang tinggi. Kelas agak curam dengan kemiringan 8-16 dengan potensi longsor agak tinggi memiliki luas 479,3 ha atau $23,8 \%$, kelas miring dengan kemiringan $4-8^{\circ}$ dengan potensi longsor sedang memiliki luas 407,3 ha atau 20,3\%, kelas landai dengan kemiringan $2-4^{\circ}$ dengan potensi longsor agak rendah memiliki luas 241,1 ha atau $12 \%$, dan kelas datar dengan kemiringan $0-2^{\circ}$ dengan potensi longsor rendah memiliki luas 259,1 ha atau $12,9 \%$,

\section{Kondisi Curah Hujan}

Hasil penglohan data menunjukkan bahwa curah hujan di daerah penelitian dengan menggunakan perhitungan Schmidt dan Ferguson. Menurut Lakitan (2002) klasifikasi Schmidt Ferguson menggunakan nilai perbandingan $(\mathrm{Q})$ antara rata-rata banyaknya bulan kering (Md) dan rata-rata banyaknya bulan basah (Mf) dalam tahun penelitian. Perhitungan menghasilkan $0 \%$ yang termasuk tipe iklim sangat basah. Hasil tersebut menunjukkan bahwa parameter curah hujan untuk kerentanan gerakan tanah termasuk dalam kategori tinggi (Gambar 2A).

\section{Intensitas Kelurusan}

Liniament density atau intensitas kelurusan $(\mathrm{Ld})$ untuk penajaman dalam penentuan zona yang memiliki intensitas kelurusan yang dominan (tinggi) (gambar 2D). Di lokasi penelitian memiliki intensitas kelurusan dari rendah sampai tinggi. Intensitas kelurusan rendah ditunjukkan dengan warna hijau memiliki rentang nilai 0-2,5 $\mathrm{km}^{-1}$, berada di hilir lokasi penelitian, Ld sedang ditunjukkan dengan warna hijau muda, dengan rentang nilai $2,5-5 \mathrm{~km}^{-1}$. Ld tinggi dengan intensitas kelurusan tertinggi ditunjukan oleh warna orange - merah dengan nilai $10-12,5 \mathrm{~km}^{-1}$ berada di bagian tengah daerah penelitian.

Setelah dilakukan pengamatan dan perhitungan yang mencangkup aspek curah hujan, kemiringan lereng, persebaran litologi, kerapatan kelurusan dan penggunaan lahan pada sub DAS Cibadak khususnya Desa Warungmenteng selanjutnya dilakukan penentuan klasifikasi potensi longsor yaitu menghitung nilai setiap aspek/komponen karakteristik Sub DAS dengan cara menjumlahkan seluruh hasil kali dari skor dan bobot pada setiap parameter.

\section{a. Total Skor Potensi Longsor}

Penghitungan nilai setiap aspek/komponen karakteristik Sub DAS dilakukan dengan cara menjumlahkan seluruh hasil kali dari skor dan bobot pada setiap parameter. Dimana skor maksimum setiap aspek/komponen adalah 5 dan nilai minimumnya adalah 1 . Nilai skor total terendah berada pada nilai 1.6 dan skor total tertinggi berada pada nilai 4.7 .

b. Klasifikasi Zona Tingkat Kerentanan Longsor Desa Warungmenteng

Berdasarkan perhitungan dan analisis yang telah dilakukan, maka dapat diklasifikasikan tingkat kerentanan potensi longsor. Daerah warungmenteng dibagi ke dalam 3 wilayah kerentanan potensi longsor:

1. Daerah dengan tingkat kerentanan gerakan tanah sangat tinggi. Wilayah ini berada pada kemiringan lereng yang miring-agak curam, penggunaan lahan yang mendominasi adalah pemukiman dan sawah, litologi berupa tuf-breksi, kerapatan kelurusan yang tinggi. Dengan kondisi wilayah yang termasuk kerentanan potensi longsor sangat tinggi, maka daerah ini perlu mendapat perhatian untuk terhindar dari permasalahan longsor 
Tabel 3. Tingkat Kerentanan Potensi Longsor Daerah Penelitian (Paimin dkk., 2006)

\begin{tabular}{|c|c|c|c|c|c|c|c|c|}
\hline \multirow{2}{*}{$\begin{array}{c}\text { Kategori } \\
\text { Tidak rentan }\end{array}$} & \multicolumn{2}{|c|}{ Kemiringan lereng } & \multicolumn{2}{|c|}{ Kerapatan Kelurusan } & \multirow{2}{*}{\begin{tabular}{|c} 
Batuan Penyusun \\
Aliran Lava
\end{tabular}} & \multirow{2}{*}{\begin{tabular}{|l|} 
Curah Hujan \\
Sangat basah \\
\end{tabular}} & \multirow{2}{*}{$\begin{array}{c}\text { Penggunaan Lahan } \\
\text { Hutan }\end{array}$} & \multirow{2}{*}{$\begin{array}{c}\begin{array}{c}\text { Nilai } \\
\text { Kerentanan }\end{array} \\
<1.7\end{array}$} \\
\hline & Curam & $>55 \%$ & Rendah & $0-2.5 \mathrm{~km} / \mathrm{km} 2$ & & & & \\
\hline Sedikit rentan & Agak Curam & $27-55 \%$ & Rendah & $2.5-5 \mathrm{~km} / \mathrm{km} 2$ & $\begin{array}{l}\text { Aliran Lava } \\
\text { terkekarkan }\end{array}$ & Sangat basah & $\begin{array}{c}\text { Semak belukar, Tegal } \\
\text { kebun }\end{array}$ & $1.7-2.5$ \\
\hline Agak rentan & Datar-Undulasi & $5-22 \%$ & Sedang & $5-7.5 \mathrm{~km} / \mathrm{km} 2$ & $\begin{array}{c}\text { Aliran Piroklastik, } \\
\text { Lava }\end{array}$ & Sangat basah & $\begin{array}{c}\text { Tegal kebun, sawah, } \\
\text { pemukiman }\end{array}$ & $2.6-3.4$ \\
\hline Rentan & Undulasi & $22 \%$ & Sedang & $5-7.5 \mathrm{~km} / \mathrm{km} 2$ & Aliran Piroklastik & Sangat basah & Sawah, pemukiman & 3.5-4.3 \\
\hline Sangat rentan & Curam & $44.20 \%$ & Tinggi & $7.5-10 \mathrm{~km} / \mathrm{km} 2$ & Aliran Piroklastik & Sangat basah & Pemukiman & $>4.3$ \\
\hline
\end{tabular}

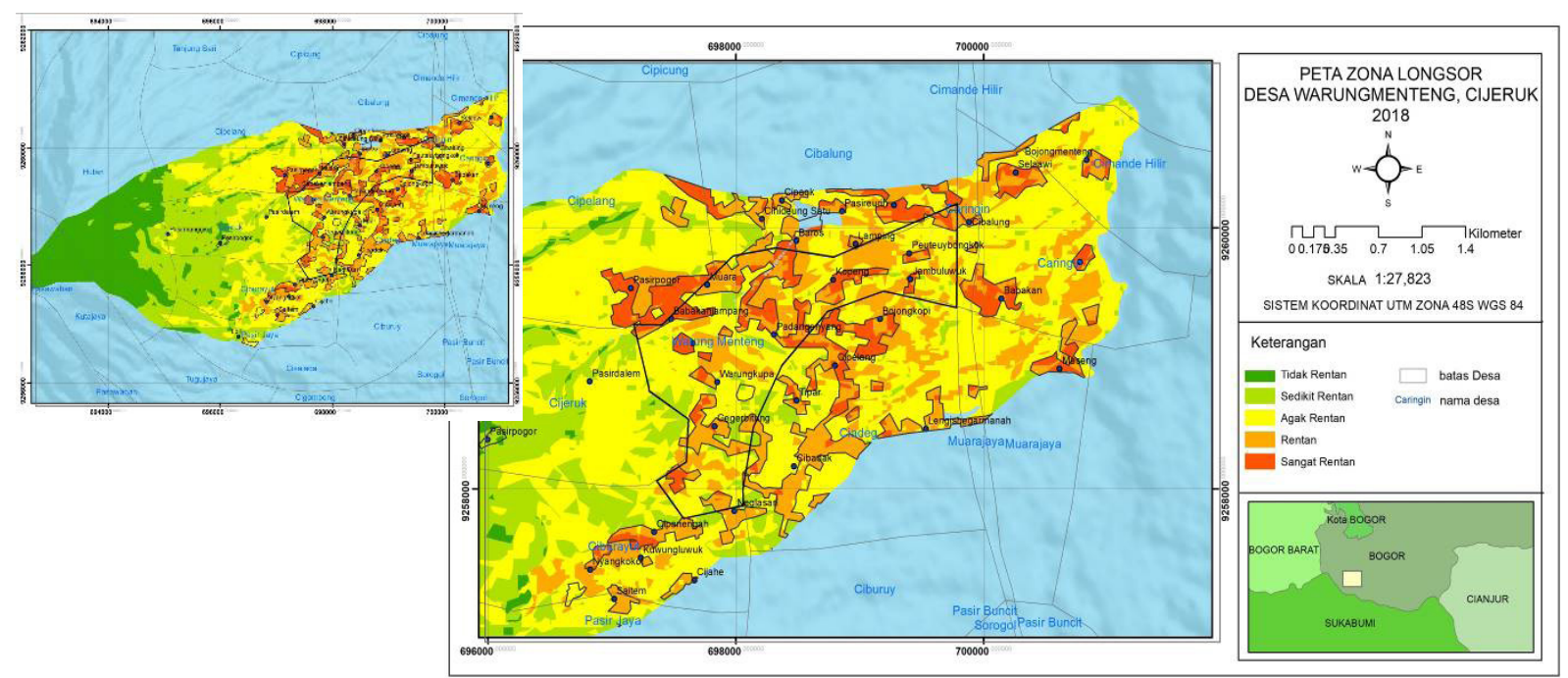

Gambar 4. Peta Kerentanan Gerakan Tanah di Desa Warungmenteng

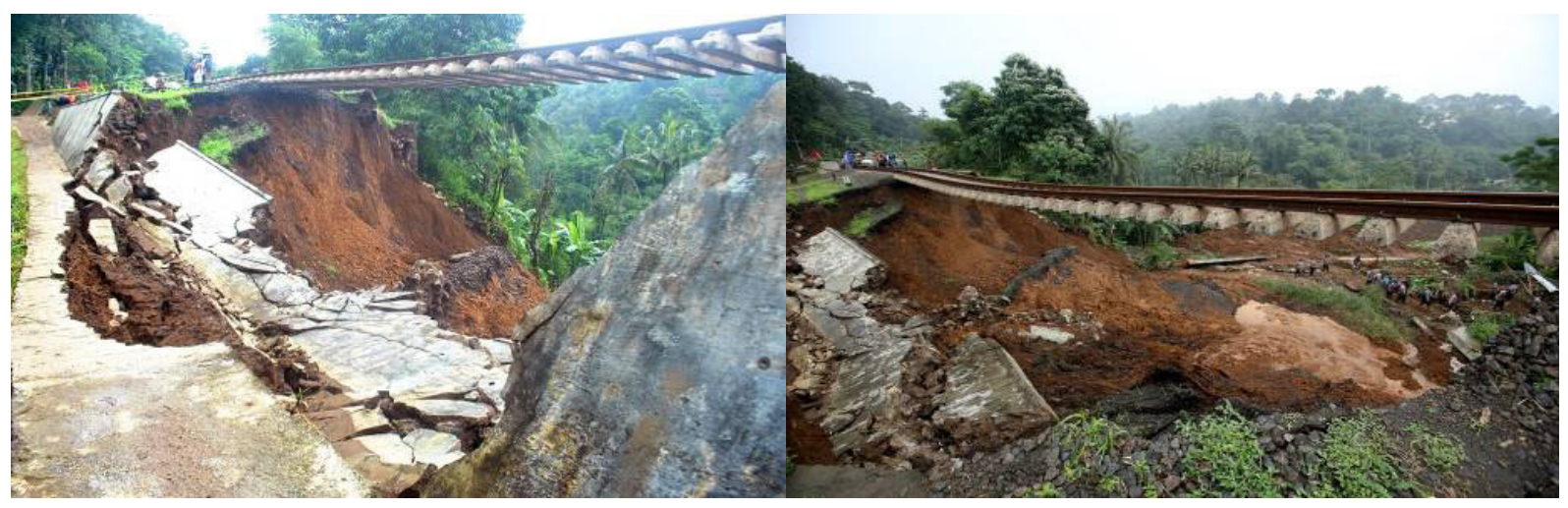

Gambar 5. Kejadian Longsor di Desa Warungmenteng, Bogor (Kompas, 2016)

2. Daerah dengan tingkat kerentanan gerakan tanah agak tinggi. Wilayah ini bearada pada kemiringan lereng yang miring, litologi berupa breksi, kerapatan kelurusan yang sedang-tinggi. Dengan kondisi wilayah yang termasuk kerentanan potensi longsor agak tinggi, maka daerah ini perlu mendapat perhatian untuk terhindar dari permasalahan longsor.

3. Daerah dengan tingkat kerentanan gerakan tanah sedang. Wilayah ini berada pada kemiringan lereng yang datar-landai, litologi berupa breksi-tuf, kerapatan kelurusan yang sedang-tinggi. Dengan kondisi wilayah yang termasuk kerentanan potensi longsor agak tinggi.

Validasi hasil penentuan tingkat kerentanan gerakan tanah dilakukan dengan analisis tumpang tindih lokasi lokasi longsor di daerah Warungmenteng dengan Peta Kerentanan Gerakan Tanah Warungmenteng (Gambar 4).
Lokasi titik longsor didapatkan dari komplikasi data-data longsor dari PVMBG (Anonim, 2013) dan hasil survei lapangan. Hasil analisis menunjukan bahwa sebagian besar lokasi longsor berada di Kampung Maseng yang disebabkan oleh hujan deras yang menyebabkan tebing longsor setinggi 30 meter dan lebar 100 meter. Longsor menimbun tiga rumah di bawahnya yang berdampak pada tiga KK beranggota 11 jiwa. Enam orang selamat dan lima orang tertimbun longsor. Lokasi longsor tersebut dengan tingkat kerentanan sangat rentan. Hal tersebut mengindikasikan bahwa kemiringan lereng dan batuan penyusun merupakan salah satu faktor yang pemicu terjadinya gerakan tanah dengan batuan penyusun breksi laharik dan tuf yang relatif lulus air, dimana kemampuan meresapkan air hujan tergolong besar, Jenis pelapukan batuan ini relatif rawan terhadap gerakan tanah bila mendapatkan siraman curah hujan yang tinggi. Dengan 
memperhatikan kondisi fisik dasar daerah perbukitan dan pegunungan yang ada, secara alami (sebelum/tanpa rekayasa) kawasan ini memiliki kerentanan lingkungan yang relatif tinggi dan dapat menimbulkan bahaya geologi berupa gerakan tanah terutama terjadi pada lahan dengan lereng yang curam, sifat batuan dan tanah pelapukan buruk, dan curah hujan tinggi. Pemukiman yang perlu diwaspadai adanya gerakan tanah diantaranya adalah Lembuluwuk, Kopeng, Padangehyang dan Babakan Jampang.

\section{SIMPULAN}

Desa Warungmenteng, Kecamatan Cijeruk mempunyai daerah yang rentan akan bencana gerakan tanah. Batuan penyusun seperti tuf, dan breksi laharik yang lulus air, kemiringan lereng yang tinggi, tataguna lahan berupa pemukiman dan sawah serta curah hujan yang tinggi menjadi faktor utama Desa Warungmenteng rentan terhadap longsor.

Klasifikasi tingkat kerentanan gerakan tanah menggunakan metode Paimin di Warungmenteng menghasilkan tiga tingkat kerentanan gerakan tanah, yaitu sedang, rentan, dan sangat rentan. Secara umum klasifikasi tersebut menunjukkan bahwa sebagian besar lokasi longsor memang berada pada daerah dengan tingkat kerentanan gerakan tanah rentan hingga sangat rentan. Lokasi longsor yang berada pada daerah dengan tingkat kerentanan sangat rentan terdapat di Kampung Maseng. Kerentanan gerakan tanah di daerah penelitian dipengaruhi oleh batuan penyusun seperti tuf, dan breksi laharik yang lulus air, kemiringan lereng yang tinggi, tanah lapukan yang tebal, tataguna lahan berupa pemukiman dan sawah serta curah hujan yang tinggi menjadi faktor utama Desa Warungmenteng rentan terhadap longsor.

\section{UCAPAN TERIMAKASIH}

Kami ucapkan terimakasih kepada pihak Direktorat Riset PPM dan Inovasi Unpad atas kesempatan dan kepercayaan yang telah diberikan, serta kepada pemerintah setempat dan warga Desa Warungmenteng atas segala bantuan dan kerjasamanya.

\section{DAFTAR PUSTAKA}

Anonim. (2018). Publikasi kinerja triwulan BPBD Agustus 2018. Diperoleh 23 Oktober 2018, dari http://bpbd. bogorkab.go.id/wp-content/uploads/2018/08/ PUBLIKASI-KINERJA-TRIWULAN-II-2018. pdf

Efendi, A.C., Kusnama dan B. Hermanto. (1998). Peta Geologi Lembar Bogor, Jawa Edisi ke dua, skala 1 : 100.000. Pusat Penelitian dan Pengembangan Geologi, Bandung.

Fauzielly, L., Lia Jurnaliah, Luthfan Harisan, Muhammad Aditio, Taufiq Hadi, dan Iqbal Jabari. (2018). Sosialisasi Mitigasi Bencana Longsor didaerah Hambalang, Kecamatan Citeureup, Kabupaten Bogor. Dharmakarya. Vol 7, No 1, Maret 2018 :11-13.

Lakitan, B. (2002). Dasar Dasar Klimatologi . PT. Raja Grafindo Persada. Jakarta.

Kompas. (2018, 06 Februari). Longsor-di-CijerukMerengut-Nyawa. Diperoleh 23 Oktober 2018, dari https:/foto.kompas.com/photo/ $\mathrm{read} / 2018 / 02 / 06 / 15178953501 \mathrm{a} 2 /$ Longsor-diCijeruk-Merengut-Nyawa

Natasia,N. (2018) Geomorfologi dan Ciri Fasies Vulkanik Pada Sungai Cihideung dan Ciparikalih, Sub Das Cibadak, Gunung Salak, Jawa Barat. Bulletin of Scientific Contribution, Volume 16, Nomor 2, Agustus 2018 : 109-116. ISSN 1693-4873.

Paimin, Sukresno, dan Purwanto. (2006). Sidik Cepat Degradasi Sub Daerah Aliran Sungai (Sub DAS). Puslitbang Hutan dan Konservasi Alam. Bogor.

van Zuidam, R.A. (1985). Aerial Photo Interpretation in Terrain Analysis and Geomorphologic Mapping, The Hague: Smits. 